\title{
An 020 Teaching Optimization Mode of Ideological and Political Theory Course in Big Data Era
}

\author{
Honghui Zhu \\ Wuzhou University, Wuzhou, Guanxi 543002, China \\ zhuhaitang@163.com
}

Keywords: Big data era; Ideological and political theory course; Teaching optimization; O2O Mode

\begin{abstract}
When entering the big data era, the course teaching of the ideological and political theory is facing new challenges. Based on deeply understanding the characteristics of the big data era, we propose an $\mathrm{O} 2 \mathrm{O}$ mode in ideological and political theory course teaching and its characteristics are also presented. For the purpose of course teaching optimization, we give four design principles of $\mathrm{O} 2 \mathrm{O}$ mode of teaching the ideological and political theory course. Finally, we explore the contents and the implementation approaches of the $\mathrm{O} 2 \mathrm{O}$ teaching mode of ideological and political theory course in the big data era.
\end{abstract}

\section{Introduction}

With the advent of the era of big data, big data is entered and profound influence on our lives. August 2015, the State Council in the "Platform for Action on the promotion of big data development" in the clear requirements: established with a large data speak, with a large data clear decision-making, the first time with the implementation of the "National Data Strategy", requiring the community to fully Thinking big data use thinking and problem solving, to break the inertia of the past traditional ways and universities as the forefront of knowledge [1]. Education must keep pace with the era of big data. The data is thinking big, big data technology. Big data methods into the Ideological and political theory teaching, optimization of ideological and political theory teaching, improve the ideological and political theory teaching effectiveness, we become a topic of the times[2].

\section{Characteristics of Big Data Era}

Victor Meyer-Schoenberg and Kenneth K. Ye said: "Big Data is a line with the development trend of the times of rapid technological development and unprecedented way, its ultimate purpose is mainly collected through the massive amount of data in the database to analyze the corresponding hardware and software, the process to obtain product information of great value, service or information is also obtain a more profound insight."'[3]Big data has a large amount of data, many data types, relatively low density and value of the data processing speed, timeliness demanding features. Big Data is a full range of changing the way people observe, analyze and grasp the way of thinking and change the path of the world, people become a source of new knowledge and create new value. In the big data era, the ideological and political theory teaching needs to concern different college student information according to the definition and characteristics of the big data, to achieve teaching optimization [4].

\section{An O2O Ideological and Political Theory Course Mode in the Big Data Era}

The Connotation of Ideological and Political Theory Class 020 Mode. Ideological and Political Theory Course $\mathrm{O} 2 \mathrm{O}$ mode is to learn online and offline $\mathrm{O} 2 \mathrm{O}$ e-commerce model, namely Online to Offline, implement innovative ideological and political theory courses teaching methods of work, to explore the use of big data and big data technology to optimize the thinking of Ideological and Political Theory new path and new model class education effectiveness. 
The Features of Ideological and Political Theory Class O2O Mode. O2O mode for students: first, get richer, comprehensive ideological and political theory teaching and expand the content information. Second, provide more convenient online consultation, communication, and interactive learning. Third, access to the line compared to classroom teaching more flexible learning time and learning.

O2O mode for teachers: First, to get more ideological and political theory education, publicity, display opportunity to attract more students to online learning and exchange. Second, access to the network, study records can be checked, can be tracked. Third, master student data greatly enhance the students' enthusiasm for learning ideological and political theory, Interest and learning. Fourth, through communication with college students, college students a better understanding of mental doubts, improve the ideological and political theory teaching effectiveness.

$\mathrm{O} 2 \mathrm{O}$ platform to the school itself: First, college students and everyday life, is closely related to learning, and learning and give students a convenient, able to attract large numbers of students access to learning. Second, the ideological and political theory has a strong educational role, to attract a large number of lines under study added.

\section{Design Principles of O2O Mode of Ideological and Political Theory Course Teaching in the Big Data Era}

A Holistic Design Teaching Content, the Formation of Large Data Thinking, Systematized and Fragmented Learning Organic Unity. In the era of big data, "multi-screen interactive", "mobile Internet" has become the norm. As human, financial and material resources, the data become the foundation of wealth and organizational innovation. We use a whole look at all the various media to their strengths, content to play out, learn from each other to create synergy, the ideological and political theory teaching to maximize the effect [5].

Ideological and political attention to the ideological and political theory teaching, in order to build problem-centered teaching content framework to analyze and solve problems outside of the classroom teaching as the core of the organization.

Pay Attention to Practice Ability Training of Marxist Theory for Students.

Focus on the Full-Time Teaching. Realize all-weather ideological and political theory teaching and supply-demand characteristics. It is so in the present mobile Internet technology and big data supported by the ideological and political theory teaching a breeze.[8] It not only reflects the "students were education initiative" Teaching deep pass that superiority, but also a comprehensive interpretation of the "media - who extended" the reality, further expanding space-time dimensions.[9]

\section{The Implementation Plan of O2O Mode of Ideological and Political Theory Course in the Big Data Era}

Online Teaching Optimization. Focus on the teaching part of the network, with the Mu class way to expand the content of teaching, the use of the course website, QQ, WeChat, E-class, e-mail and other online platform to interact with teachers and students of teaching materials and textbooks.[11]

Offline Optimization Scheme. Offline teaching program focused on classroom teaching part, teachers and students to achieve face to face with the flipped classroom teaching way, teaching. We designed the course content teaching the theory to the problem of consciousness as a precursor to the topic of teaching as a means to the student group learning as a unit, consisting of theoretical teaching school teachers team and discuss the instructor team, research-based teaching, improve teaching Effectiveness .

Our theoretical teaching is divided into three phases. Theoretical teaching theory taught a lesson pm 3 hours, 2 hours of self-study guide, a panel discussion 2 hours three links, teaching contents and requirements of each segment are as follows:

Theory teaching: Teachers using heuristic, case-based, interactive teaching methods, etc., take the form of thematic focus each section succinctly, difficult and hot issues, and the new theory and 
research results in a timely manner to enrich the teaching content. Through theoretical lectures, students are actively to master the basic principles of curriculum and basic methods, theoretical basis for the two areas after entering. Teachers, as required, in the theory taught design courses teaching materials and courses to expand the thematic topics. By expanding learning, expand their knowledge, so that students in a comprehensive understanding of teaching materials at the same time, but the initial construction disciplines of knowledge from a macro point of view, and learn to apply theoretical knowledge.

Self-study guidance: This link is to guide students according to self-study outline, self-study thematic chapters, by answering questions form to help students consolidate the learned knowledge of each chapter, grasp key, solve the difficulty, eliminate confusion, to prepare for the next link of learning.

Group discussion: Students usually six for a study group, the topic study group according to the teacher for discussion. Under the guidance of teachers, fully expand reading formed on the basis of the conclusion, in the form of homework submission on interactive network platform, teacher group discussion results in a timely manner to the student review and summary.

The Combination of Online Solutions. Online program focuses on the combination of the first class and second class teaching, practice teaching ways to achieve the internalization and externalization of teaching material contents. It provided comprehensive practice of ideological and political theory courses.

The form of ideological and political theory practice course includes four forms. The first one is researching. The second is visiting and reading classes. The third one is public service activities category. The fourth is the competition category. The research class, reading class, public interest action classes as the basic classes, students must complete the corresponding credits; racing, etc., for elective classes, students to participate in the competition to obtain credits, credits can be arrived in public interest action classes.

Organize and implement. Student affairs office and Communist Youth League of university together to build ideological and political theory class integrated practice management system, establish an account for each student, and publish the relevant requirements of practical classes at the site, including a clear practical classes belonging to the scope of the types of activities and a variety of learning activities commuted fraction. Student login account, fill out the registration form to complete on their own practice course.

\section{Conclusions}

Big data transformed the way we live, work and thinking. The big data is nothing else but a resource we can utilize. It contains opportunities and risks. Our ideological and political theory needs us change and keep moving in order that the ideological and political theory teaching in the big data era provides better servers for our students.

\section{Acknowledgements}

This article is supported by 2015 Guangxi universities ideological and political education theory and practice subject "O2O mode of ideological and political theory course teaching optimization in the big data era".

\section{References}

[1] Viktor Meyer-Shon Kenneth: Big Data: A Revolution That Will Transform How We Live, Work, and Think, Hangzhou: Zhejiang people's publishing house, 2013 
[2] The Education department of ideological and political theory course construction system innovation plan" to teach social science in colleges and universities [2015] no.2[EB/OL]. Information on http://www.moe.edu.cn/srcsite/A13/moe_772/201508/t20150811_199379.html.

[3] D. Bai: Research on the teaching of ideological and political education theory course in Universities in the Era of big data, Journal of higher education BBS, (2014) No.10,p. 28- 30 (In Chinese)

[4] The Education department of ideological and political theory course construction system innovation plan" to teach social science in colleges and universities [2015]no.2[EB/OL]. Information on http://www.moe.edu.cn/srcsite/A13/moe_772/201508/t20150811_199379.html.

[5] G.J .Wang, Sh. Liu: Research on college students ' ideological and political education in the age of big data, Theoretical observation, (2014) No.1, p.143-144 (In Chinese)

[6] Sh.X. Hu, Y.J. Xie: Network ideological and political education in the era of big data [J]. Ideological Education Research, (2013) No.6, p. 60-61 (In Chinese)

[7] Z.Y. Hu: Ideological and political education of college students facing the era of big data and response , School Party and ideological education. (2014) No.7,p.65 (In Chinese)

[8] R.Zhang, Zh. Dong: Ideological and political education exploration in big data era, School Party and ideological education, (2014) No.5,p .67(In Chinese)

[9] H.J. Li, H. Xia: The innovation of ideological and political education mode in Universities in the era of big data, Ideological Education Research, (2015) No.5,p .48-51. (In Chinese)

[10] H. Liu: Micro Propagation of the big data era of ideological and political education [J] Ideological and Theoretical Education, (2014) No.6, p .81-85. (In Chinese)

[11]Z.X. Hu, J. Yu: Study on the carrier of Ideological and political education in the era of big data and Its Countermeasures, Ideological Education Research, (2015) No.2,p.74-77(In Chinese) 